\title{
パッケージ自動組立ロボット*
}

片山茂井戸繁河田紘一

1. は じめに

近年, 電子部品の小型化, 高集積化により, プリント 基板の部品密度, 実装密度は非常に高くなって招り（写 真 1), 電子機器の小形化, 高性能化, 低コス卜化は急激 に変化している．これに伴いプリント基板への組立作業 の自動化も急速に進んでいる.

従来, プリント基板への実装組立は, 典型的な学働集 約形の生産形態がとられ, 同一ライン内で十数名の作業 者が手挿入で部品リード端子を丸穴 (スルーホール)へ 插入して, パッケージ（プリント基板へ電子部品を組込 んだもの) 組立を終えていた. この組立工程はパッヶー ジ 1 枚の数十\%を占めるコストがかかり，コスト低減, 品質向上の点からも自動化が強く望まれていた.これに 対し昭和 40 年代中頃より特定部品の自動插入機が実用 化され, 現在では, IC, ラジアル部品, アキシャル部 品, 異形部品等の専用自動挿入機が市場に出回り, 一部 品 0.3 秒の高速自動挿入が可能となっている.

一方, プリント基板のパターンは IC, LSI と同梯に 高密度, 微細化か゚進み,ピン間 3 本 (0.1 インチのラン ド間に回路パターンか゚ 3 本通るるの) 以上が実用化され ており, 実装部品密度も非常に高くなっている.

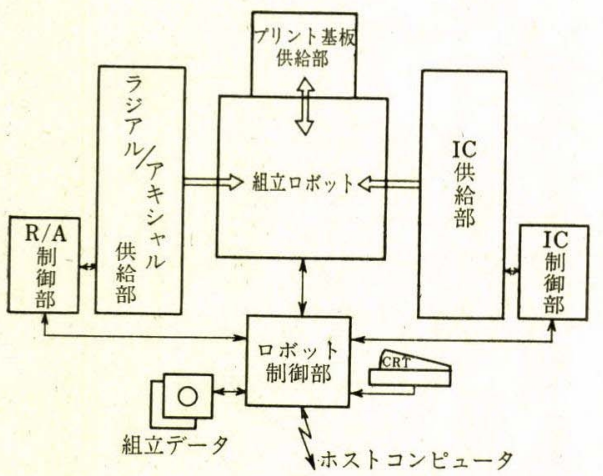

図 1 パッケージ自動組立ロボットの構成図

原稿受付 1983 年 5 月 10 日

* Package Auto-Assembly Robot
さらに，実装する部品の形状も多種類にわたり，従来 の専用機では, 例党ば IC 挿入後, 隣接するラジアル部 品が実装できなくなり，したがって後工程で作業者が手 作業で插入するようになり，自動実装効率が下がる場合 もおきている.このためには, 基板実装順に従って 1 台 の挿入機で, ラジアル部品, アキシャル部品, IC, …... 等を插入してゆく必要が出てくる.

\section{2. パッケージ自動組立ロボットの構成}

本装置は一台のマシンで IC, ラジアル，アキシャル 部品を基板の実装順に従って自動挿入するものである.

図1に構成図を示す.

構成は、テーピングされた 60 種のラジアル，アキシ ヤル部品をりードカット，フォーミングするラジアル/ アキシャル供給部, 70 種の IC を供給する IC 供給部, 及びプリント基板を組立ロボット内へ搬送するプリント 基板供給部とから成り，ロボットハンドを使用して指定 された基板の穴へ部品を挿入している.

制御方式は, 組立ロボットを制御するロボット制御部 をマスタコンピュータとし, 各供給部の制御部はスレー プコンピュータとして、ロボット制御部からの指令によ り全体を動かす方式を採用している。ロボット制御部に はパッケージ組立データをオンラインで供給するホスト

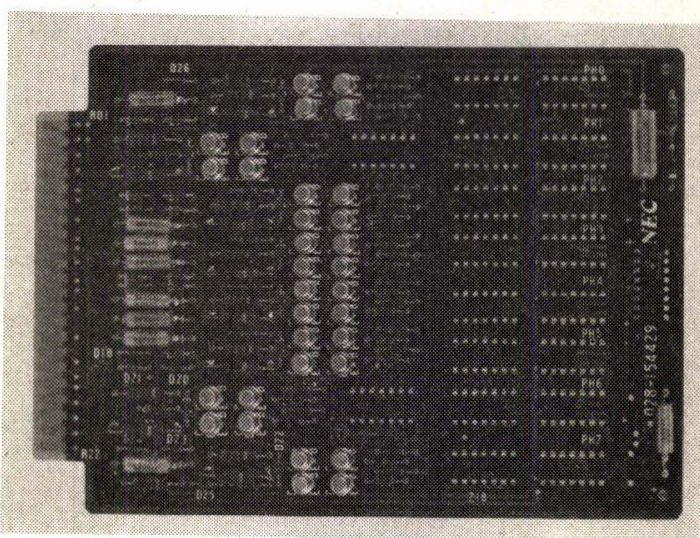

写真 1 高密度実装パッケージ 
・基板データレコード

\begin{tabular}{|l|l|l|l|}
\hline 区分 & 基板名 & サイズ & イ゚ンチ \\
\hline
\end{tabular}

・実装部品のデータレコード（一部品当り）

\begin{tabular}{|l|l|l|l|l|l|l|l|}
\hline 部品区分 & 部品名 & ステーションN0. & 実装方向 & X座標 & Y座標 & ピン数 & R \\
\hline
\end{tabular}

\begin{tabular}{|c|c|c|c|}
\hline ピッチ数 & リード径 & 挿入モード & 定 数 \\
\hline
\end{tabular}

図 2 パッケージ組立データフォーマット

コンピュータとの接続インターフェイスと, オフライン でも動作できるようフロッピーディスクを接続している。 パッケージ組立データは，パッケージ 1 枚当り平均 $4 \mathrm{k}$ バイトの容量があり, 各供給部へ $40 \mathrm{k}$ ボーの高速度で DMA 転送を行っている.

\section{3. パッケージ組立データ}

プリント基板へ部品を実装していくための組立データ は，図2 亿示すように先頭に基板データレコードを持っ ている.このレコードは基板名, 基板サイズ, 格子目の ピッチの分類コードで，基板位置決め及び実装ピッチ幅 情報として使用される，このレコード以降には，実装順 に従った部品のデータレコードが並んでいる。このレコ ード内の部品区分は供給部の指定を行うもので, ステー ションNo.コードから対応する部品を収納したステー ションを選択していく．実装方向 $\left(0^{\circ}, 90^{\circ}, 180^{\circ}, 270^{\circ}\right)$, $X Y$ 座標 (格子ピッチ数), ピン数等のレコードはロボ ットハンドの位置, 角度, 幅等の情報である.

\section{4. ソフトウエア構成}

パッケージ組立ロボットのソフトウェアは, 図3に示 す基本ソフトウェアと, 図4 亿示す応用ソフトウェアに

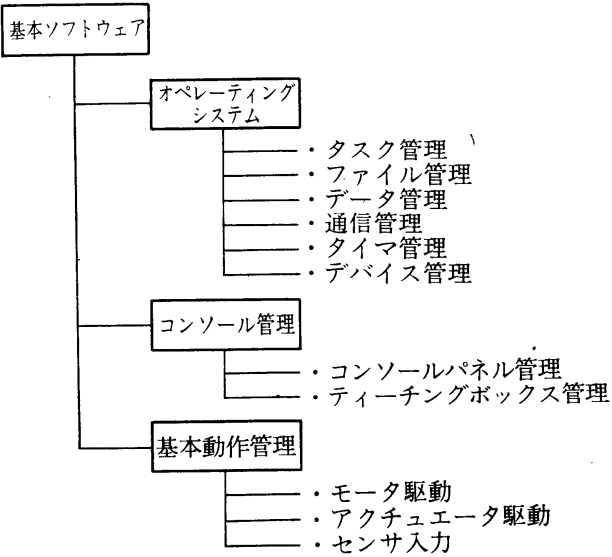

図 3 基本ソフトウェア構成図
分けることができる.

基本ソフトウェアは，各制御部に共通したソフトウエ アでリアルタイム・マルチタスク処理が可能なオペレー ティングシステムと，オペレータパネルやティーチング ボックス等のオペレータコンソールを制御するコンソー ル管理と，モータ，アクチュエータ，センサ等ロボット， 供給部の標準的なデバイスを制御する基本動作管理で構 成されている.

応用ソフトウェアはパッケージ組立ロボットに固有の ソフトウェアで, オペレータとの会話により動作モード 設定, ホストコンピュータとのデータ通信, データチェ ックやメンテナンス等各種操作への分岐を行ら会話処理, 及びパッケージ組立データを解読し, 各供給部へ分配す る組立データ変換処理，ハッケージ組立のシーケンス制 御を行う組立動作処理, 生産管理データや稼動状況デー タを収集する管理データ収集処理, システムの故障診断 を行らシステムメンテナンスで構成されている。

次に, ソフトゥェアの動作について図 5を使用して概 要を述べる. 図 5 はシステムの動作状態の遷移してゆく 様子を示したものである. 電源 ON で会話処理に制御 が移り，動作モード設定を行い，必要ならばホストコン ピュータとの通信処理，システムメンテナンスへの分岐， 及びファイルを参照してデータ内容のチェック等を行う. 次に，組立開始の指令によりパッケージ組立動作へ制御 が移る。まず組立データの解読から始まり，プリント基 板のセット，部品供給を待って組立が開始される.

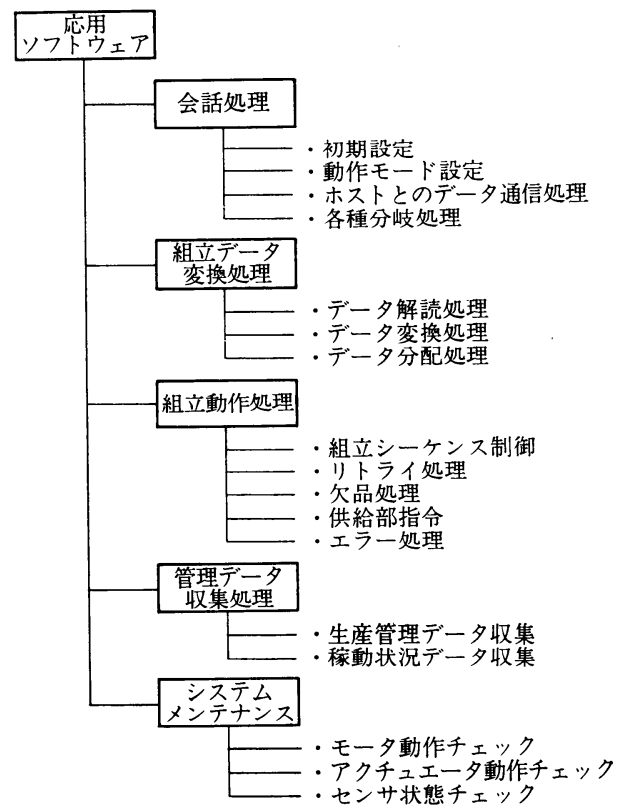

図 4 応用ソフトゥェア構成図 


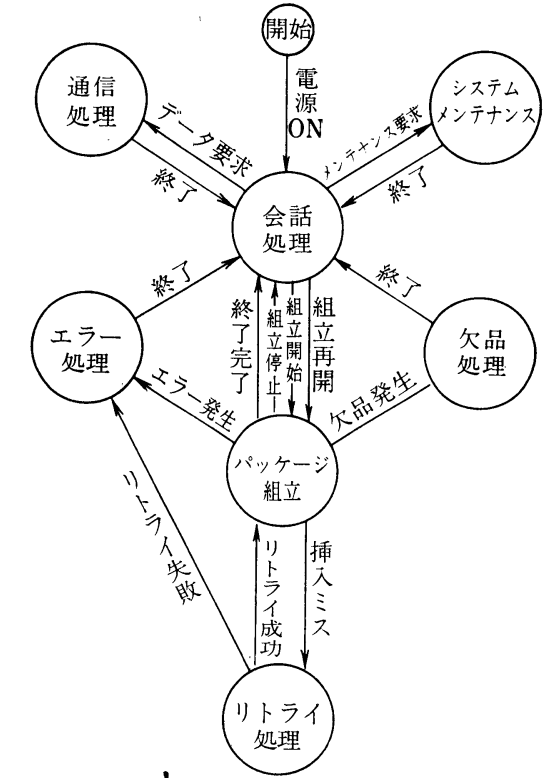

図 5 パッヶージ組立ロボット動作状態遷移図

組立途中で供給部品の不足や欠品が発生すると欠品処 理へ制御が移る.この場合 CRT 上に部品情報が表示さ れるので，作業者が部品補充または欠品指定を行い，会 話処理へ戻り，組立再開となる．作業者が欠品指定した 部品は以後組立の対象とならず，管理データが作成され る. 管理データとは，欠品や組立ミスがあるために製品 として未完成であることを示すもので, 後工程での手組 立に対する指示情報となっている.

\section{5. ロボットハンド}

組立ロボットには IC 専用のハンド（図 6) と, ラジ アル/アキシャル用のハンド 2 本を持っており, 各々独 立して動作するようになっている．各ハンドの上下動作

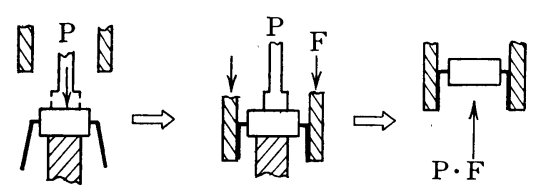

a) 部品取り出し

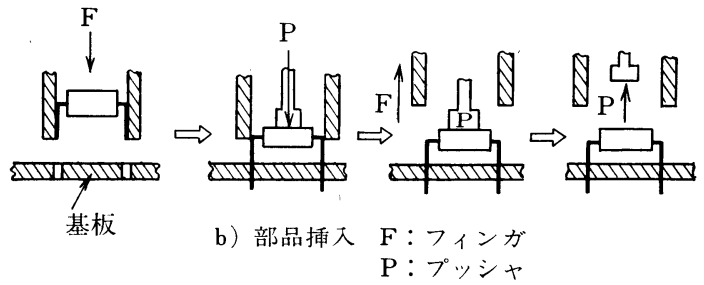

図 7 IC, アキシャル部品の取り出し, 挿入

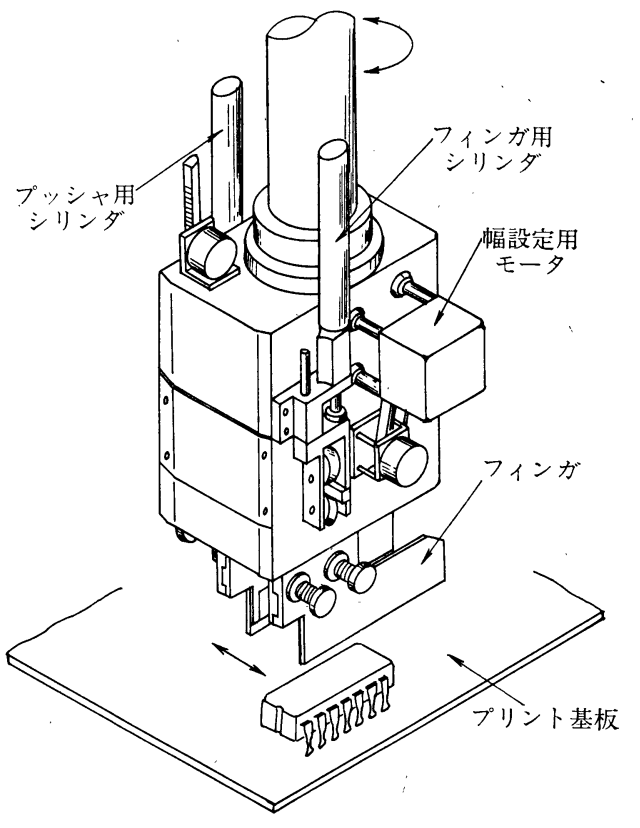

図 6 IC 用ロボットハンド

は，高速性，振動を少なくするため，ハンド内でェアシ リンダ駆動を行い, $X Y$ 移動はハンド自体をリニアモー タで駆動し高速化を図っている．特にハンドの移動時間 がインデックスに関係してくるため, ハンドの移動を高 速で行う必要がある.このためハンド自体に軽量合金を 採用し，重量を $2 \mathrm{~kg}$ 以下に抑兄，立上り，立下り時間 $0.05 \mathrm{~s}$, 最高速度 $800 \mathrm{~mm} / \mathrm{s}$ を実現している.

図7に IC，アキシャル部品の取り出し，挿入動作を 示す. 実装密度の高いプリント基板への部品挿入に対し ては, 挿入前にハンドフィンガの側面で隣接部品の倒れ を矯正して挿入を行っている.

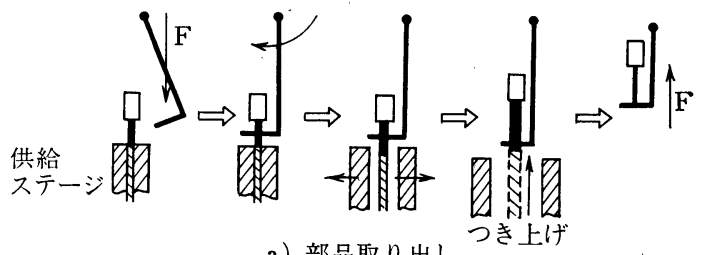

a) 部品取り出し

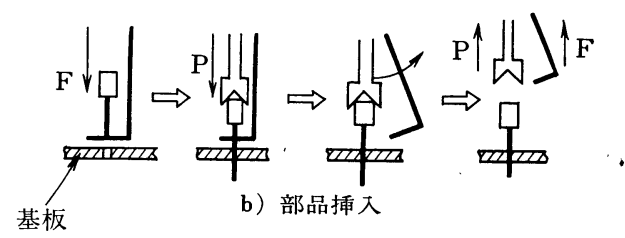

図 8 ラジアル部品の取り出し, 挿入 
片山茂井戸繁河田紘一

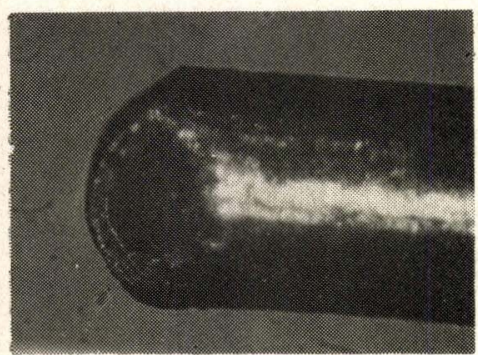

\section{写真 2}

アキシャル部 品リート゚先端 $\mathrm{V}$ カットの拡大 （倍率 $\times 60$ )

\section{6. 高挿入率への対応}

挿入ミス（部品の高さ，挿入圧，リード寸法で検出） が生じると, この部品をロボットハンドで取り出し廃棄
して,さらにロボット制御部から該当する部品供給部へ 部品名の指令を行い，再供給して挿入を行っている.

また本装置では $0.8 \phi$ のスルーホール径への部品插入 を安定して行えるよう, 部品リード端子カット時, 先端 を $\mathrm{V}$ カット (写真 2) して挿入率の向上を図っている.

\section{7. おわりに}

電子部品の超小形化, 高集積化, 多ピン化は今後ます ます増大していく傾向にあり，パッケージ組立作業も微 細化, 高速化, 複雑化したものとなり, 組立装置には, 無人化 $($ 夜間運転) $=$ 高信頼性 (高安定度) の高いものが より強く要求され，高度な技術を必要とするロボットの 応用分野となると思われる。

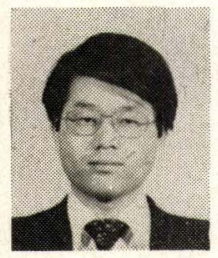

片山 茂 (Shigeru KATAYAMA)

昭和 25 年 1 月 12 日生れ. 昭和 51 年 3 月山梨大学精密工学科修士課程終了. 同年 4 月日本電気(株)入社. 生産自動化 開発本部ロボット開発部に扑いて, 自動 機械, 組立用ロボットの開発に従事. 精 機学会会員.

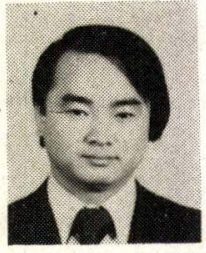

井戸 繁 (Shigeru IDO)

昭和 24 年 12 月 8 日生れ. 昭和 47 年 3 月電気通信大学 通信工学科卒業. 同年 4 月日本電気(株) 入社. 生産自動化開発本部ロボット開発 部主任. CAM システム, ロポット言語 等ソフトウェアの研究開発に従事. 精機 学会, 日本ロポット学会会員.

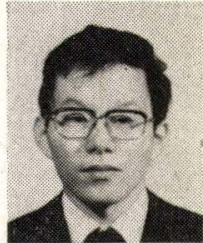

河田紘一

(Kouichi

KAWATA)

昭和 19 年 12 月 2 日生れ. 昭和 42 年 3 月早稲田大学理工学部電気工学科卒 業. 同年 4 月日本電気(株)入社，生産自 動化開発本部ロボット開発部技術課長. 画像処理を応用した生産設備装置の研究 開発に従事. 電気学会, 計測自動制御学 会情報処理学会会員.

\section{ロボットと“共生”めざす}

一第 21 回医学会総会

最近の医学の進歩は, エレクトロニクス, バイオテク ノロジーなと゚工学の発展と相互作用にある. そこで, 過 日大阪で開かれた「第 21 回日本医学会総会」から先端 技術に光をあてながらトピックスを紹介しよう.

診断, 治療を補完したり, 損傷を受けた生体の身代わ りとしてのロボット技術の進歩にも期待がかかる. $\mathrm{ME}$ 機器の多くがそらた゚ったよらに，ロボットについても産 業用の技術を医療に生かす試みが積極的に行われている。

操縦型からスタートしたロボットの歴史は, 現在では 自動型の全盛期を迎えており,さらに知能ロボットなど 自律型への展開が始まっているが，医用には，過疎地や 宇宙など遠隔地に拈いても治療のできる高度な操 縦 型
と，微妙な皮膚感覚を持った，人䇥の手と全く同じ働さ を行うような自律型を併用していくことになろう.

現状では医療機関での運搬用などの自動型は別にして も，人工蘇生術訓練など教育用や身体障害者の義手，義 足なと゚には，かなり生体の機能に接近したものが登場. 今後は治療そのものにも広範囲に活躍しよう.

10 年後には医師の補安的治療のうち多くの部分を補助 し, 20 年後は, 医師の領域にもタッチ,さらに 50 年後 には医師とロボットだけで医療チームが構成されると見 られている.

産業用ロボットでは, “省人化”“自動化”が究極目的 だとすると医用は将来においてもそうではなく，あくま でも治療の補助，あるいは機械が人間の地位を奪うので はなく，“共生”を目指してのロボット開発，利用が急速 に進んでいる. 